\title{
Bacterial organomercury lyase: a protonolytic detoxification catalyst
}

\author{
Christopher Walsh, Tadhg Begley, Alan Walts \\ Departments of Chemistry and Biology \\ Massachusetts Institute of Technology \\ Cambridge, MA 02139
}

\begin{abstract}
Bacteria became resistant to organomercurials by enzyme-catalyzed protonolytic fragmentation of the $\mathrm{C}-\mathrm{Hg}$ bond by the enzyme organomercury 1yase to hydrocarbon and mercuric ion products. The gene encoding the enzyme has been subcloned, expressed, and the lyase purified to homogeneity and analyzed for specificity and catalytic mechanism. The retention of stereochemistry as endonorbornyl mercurial is converted enzymically in $\mathrm{D}_{2} 0$ to endo- $_{1}-$ norbornane and lack of other detectable radial pathways support an $S^{2}$ pathway where $C-H$ bond formation and $\mathrm{C}-\mathrm{Hg}$ cleavage occur in a single transition state.
\end{abstract}

\section{INTRODUCTION}

Among natural constituents in the environment are metals, usually in ionic form, some of which are toxic to cells and organisms, while others are essential components in jiochemical processes. Williams and Silver (1984), have noted that volcanic soils and deep sea vents for example, have high concentrations of toxic heavy metals and have evolved specific and often sophisticated systems for resistance to metals. Bacterial resistance to such species as cadmium(II) and silver(I) ions are usually at the level of exclusion in uptake or active export of the metal ions back out of the cell. In the case of mercury toxicity, the metal is transformed by oxidation-reduction enzymology and by reversible conversion to organometallic species. The biochemical mechanism for metabolism of and resistance to organomercurials and inorganic mercury salts is the most well. understood and is the focus of this paper.

The most common ore of mercury is red cinnabar (HgS), and this is the main anthropogenic source of metallic mercury by aerobic heating. Cinnabar from the Almaden mines in Spain has up to 78 mercury in the ore. Some $10^{10}$ tons of rock (av $80 \mu \mathrm{gg} / \mathrm{Kg}$ ) are weathered globally per year, releasing 800 tons of mercury into the environment and the total oceanic reservoir of mercury is estimated at 200 million tons. The reservoir of volatile forms of mercury $\left(\mathrm{Hg}^{\circ}\right.$ and $\mathrm{CH}_{3} \mathrm{HgX}$ ) in the atmosphere is about 4 million tons with an annual flux between these reservoirs of $\sim 15,000$ tons. The consequent dissolved $\mathrm{Hg}$ concentration in water is ca $0.03-2.0 \mu \mathrm{g} / 1$ (i.e. up to $10^{-8} \mathrm{M}$ ).

Mercuric salts are biomethylated with methyl coenzyme $B_{12}$ to methyl mercuric salts and this organomercurial is a potent human neurotoxin, evidenced by the Minamata tragedy in Japan where $\mathrm{Hg}$ Iumped from a oxymercuration plant led to accumulation of toxic levels of methylmercury in shellfish ingested by the townspeople. Bacteria have developed a two stage two enzyme detoxification strategy for recycling organomerurials back to nontoxic, volatile, elemental $\mathrm{Hg}^{\circ}$. As noted in Scheme 1, one enzyme, organomercury lyase, catalyzes a protonolytic cleavage of a carbon-mercury band, e.g. to yield methane and $\mathrm{Hg}^{\text {II }}$ from a methylmercuric salt. The second enzyme, mercuric ion reductase, reduces $\mathrm{Hg}^{\mathrm{II}}$ to $\mathrm{Hg}^{\circ}$ at the expense of stoichiometric oxidation of the NADPH coenzyme. While both RHgX and $\mathrm{Hg}$ II. salts are toxic by virtue of coordination to protein sulfhydryl groups, $\mathrm{Hg}^{\circ}$ is inert and nontoxic and volatilizes out of the bacterial cell. The genes that encode these enzymes and so confer resistance to mercurials are in general plasmid encoded and often on

Scheme I

Bacteria : Synthesis of Methylmercury and its Recycling to $\mathrm{Hg}^{\circ}$ a) $\mathrm{Hg}^{\mathrm{II}}+\underset{\mathrm{B} 12}{\mathrm{CH}_{3}} \longrightarrow \mathrm{CH}_{3}-\mathrm{Hg}-\mathrm{X}+\mathrm{BI2}$
biomethylation of mercury
b) $\mathrm{CH}_{3}-\mathrm{Hg}-\mathrm{X} \longrightarrow \mathrm{CH}_{4}+\mathrm{HgX} 2$
protonolytic cleavage of methylmercury
c) $\mathrm{HgX}_{2}+\mathrm{NADPH} \longrightarrow \mathrm{Hg}^{\circ}$
reduction of $\mathrm{Hg}^{\text {II }}$ to elemental $\mathrm{Hg}$ 
transposable elements within the plasmids, are inducible with low levels of mercurials, and are widespread, both in bacteria in soil and in aquatic environments (up to 1 in 10 bacteria) and in clinical isolates of drug resistant bacteria. Other plasmid determined resistances to toxic metals in bacteria include nickel, arsenic, antimony, cobalt, chromium, silver, cadmium, and copper (Will lams and Silver, 1.984).

The genes for mercury resistance are clustered together in a functional operon and a typical organization is illustrated in scheme II. The merR gene encodes a regulatory protein which, by binding to the operator region of the DNA in response to intracellular $\mathrm{Hg}$ II concentrations, controls whether the structural genes of the mer operon are on or off. MerT and mer $P$ encode membrane and periplasmic proteins required to transport $\mathrm{Hg}$ II into the cell where the mer A gene product, the reductase, detoxifies it by reduction. In some, but not all $\mathrm{Hg}^{\mathrm{II}}$-resistant organisms, the mer $\mathrm{B}$ gene is present, encodes the lyase and enables resistance to organomercurials as well. We have constructed overproducers for the mer B, mer A, proteins, purified them to homogeneity, and begun to characterize them for structure and function (Begley, Walts, Walsh, 1982). We summarize studies below on the unusual organometallic cleaving enzyme encoded by the mer $B$ gene.

\section{Scheme II}

Mer Operon - Genes for Resistance to Mercurials

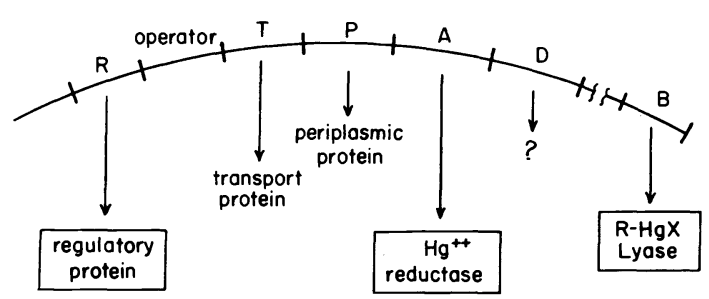

$$
\begin{aligned}
& \text { Under study : } \text { mer } \mathrm{R} \longrightarrow \text { regulatory protein controlling mer } \\
& \text { DNA activity } \\
& \text { mer } A \longrightarrow \text { enzyme detoxifying } \mathrm{Hg}^{++} \text {by reduction } \\
& \text { to } \mathrm{Hg}^{\circ} \\
& \text { mer B } \longrightarrow \text { enzyme cleaving organomercurials } \\
& \text { to } \mathrm{RH} \text { and } \mathrm{Hg}^{++}
\end{aligned}
$$

\section{Scheme III}

Mechanistic Pathways Available for R-HgX Cleavage

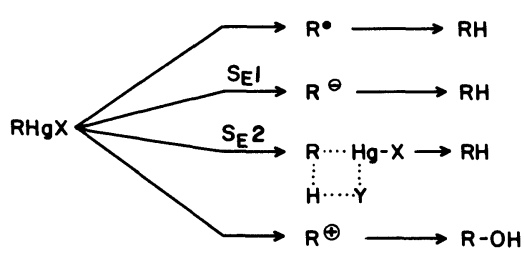

Mechanistic Route Dependant on Substrate Structure and $\mathrm{C}-\mathrm{Hg}$ Cleavage Conditions

\section{MER B GENE PRODUCT: ORGANOMERCURY LYASE}

Carbon metal bonds are quite rare in biological systems, where the best studied example is the carbon-cobalt bond in coenzyme $B_{12}$ (Halpern, 1985). Carbon-nickel bonds may be generated during carbonyl insertion processes to make acetyl units by the enzyme carbon monoxide dehydrogenase (Ragsdale and Wood, 1985). Organomercurial species, unlike many other carbon-metal compounds are very stable to protonolysis, with less than 18 protonolysis of methyl mercuric chloride by concentrated HCL in 100 minutes. Thus the job of organo mercury lyase is not a trivial one. While protonolysis of diorganomercurials has been studied (Jensen and Rickborn, 1968), less was known about the slower protonolysis of organomercurial salts and proposals involving carbanion, radical, and carbocation species have been proposed (Scheme III) with various substrates.

We have manipulated the mer $B$ gene from plasmid R-831 to place it behind the bacteriophage $\mathrm{T} 7$ promotor and allow expression of the gene for overproduction of the encoded organomercurial lyase to $3 \%$ of the soluble cell protein. This has permitted purification of enzyme to homogeneity in $25 \mathrm{mg}$ quantities. It is a catalyst of 22,400 molecular weight (about 210-220 amino acid residues) and contains no metal ions or other cofactors for the organomercury protonolysis. Broad substrate specificity, for primary, secondary and tertiary (t-butyl) alkyl mercurials, vinyl allyl, and aryl mercurials is observed. The enzyme is relatively sluggish in turnover, with values of 1 cleavage per minute for methyl mercuric chloride and t-butyl mercuric chloride, $15 \mathrm{~min}^{-1}$ for $\mathrm{n}$-butyl mercuric chloride to butane, for vinyl mercuric chloride to ethylene, for phenyl mercuric acetate to benzene. There is no detectable methane formation from dimethyl mercury. The enzyme require thiols in the buffer for activity, probably both for presentation of substrate as RHgSR' salt and to assist removal of product $\mathrm{Hg}^{\text {II }}$ from the enzyme as the $\mathrm{Hg}^{\text {II }}$ $\mathrm{SR}^{\prime}$ bisthiol complex (Begley, Walts, Walsh, 1986a).

To assess the possible mechanistic routes of scheme III, we determined that $\mathrm{CH}_{3} \mathrm{HgCl}$ yields $\mathrm{CH}_{4}$ and $\mathrm{Hg}$ II at equal rates, ruling out the solvolytic $\mathrm{S}_{\mathrm{N}}{ }^{1}$ carbocation, $\mathrm{Hg}^{\circ}$ route $\mathrm{ab}$ initio. The $\mathrm{S}_{\mathrm{E}}{ }^{1}$ route via carbanion intermediate is also highly unlikely, proceeding in the nonenzymic cases only when the resulting carbanion is particularly stabilized (Dodd 
\& Johnson, 1969, Coad and Johnson, 1967; Hughes et al, 1964), not obviously the case in the above enzymic substrates. The homolytic radical cleavage pathway, $\mathrm{s}_{\mathrm{H}}{ }^{2}$, has been shown nonenzymically for protonolysis of diorganomercurials but not conclusively for organomercurial salts (Ingold and Roberts, 1971). The last alternative, a concerted $S_{E}{ }^{2}$ cleavage with simultaneous $\mathrm{C}-\mathrm{Hg}$ cleavage and $\mathrm{C}-\mathrm{H}$ formation, has been suggested with vinyl mercurials, diorganomercurials, and alkylmercurials (Jensen and Rickborn, 1968; Kreevoy, 1957; Kreevoy and Hansen, 1961). We have used probes for stereochemistry and radicalbased rearrangements to attempt to distinguish between $S_{\mathrm{H}^{2}}$ and $\mathrm{S}_{\mathrm{E}} 2$ mechanisms used by the enzyme (Begley, Walts, Walsh, 1986b).

\section{STEREOCHEMICAL AND RADICAL PROBES OF ORGANOMERCURY LYASE}

Thus cis-butenyl mercuric chloride 1 is processed, with the highest turnover of any substrate detected ( $240 \mathrm{~min}^{-1}$, to cis-butene without detectable trans-butene (18 detection limit by GC analysis). Also the endo norbornyl mercurial 2 , is cleaved enzymically in $D_{2} O$ to the 2-D-norbornane with deuterium only at the endo position as monitored by FTIR which can distinguish the C-D stretches for endo and exo-2-D $D_{1}$-product. The high degree of configurational retention (Scheme IV) is consistent with an enzymic $S_{E}{ }^{2}$ process ratherthan a radical route which would have been expected to yield some trans butene ( $35 \%$ on full equilibration) and exo- $D_{1}$-norbornane respectively.

\section{Scheme IV}

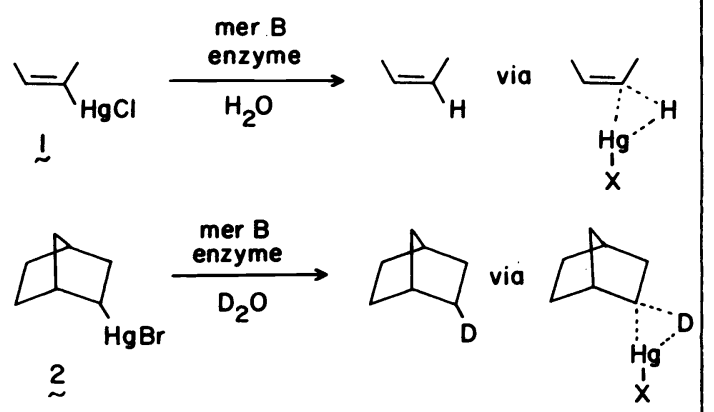

\section{Scheme VI}

Enaymo $\rightleftharpoons E \cdot R-H_{g} \rightleftharpoons E \cdot H_{g}+R H \rightleftharpoons E+H_{g}(\mathrm{II})$

Enzyme + R-Ho $-\mathrm{SR}^{\prime}$
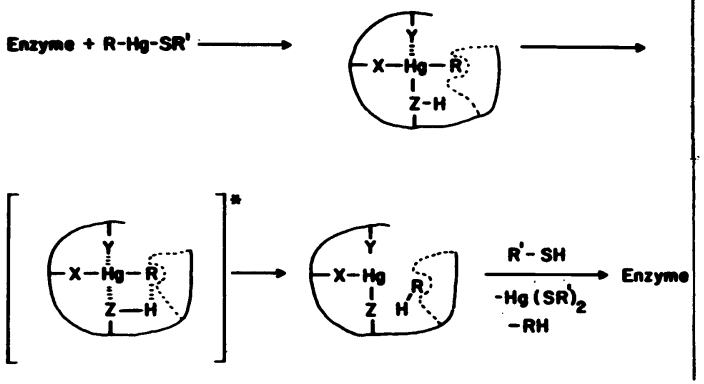

\section{Scheme V}

A Radical Probe in Reductive Demercuration of Alkyl Halides: Nonenzymic Reaction with $\mathrm{NaBH}_{4}$

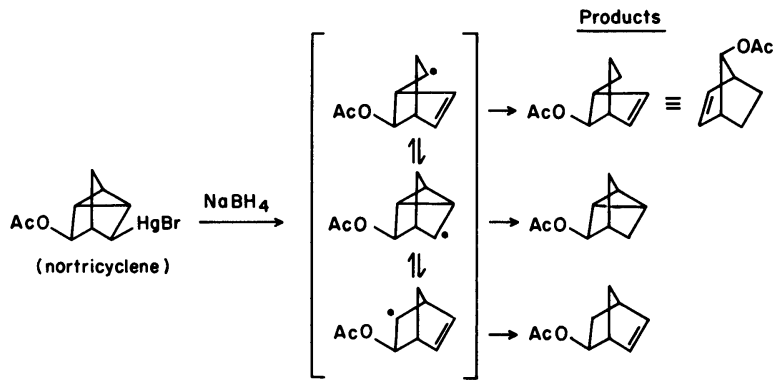

Three products $\rightarrow$ interconverting radical species

G.M. Whitesides + J. San Filippo, Jr.

J.Am.Chem.Soc. $1970,92,6611$
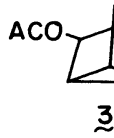<smiles>O=C(OC1C2C=CC1C2)C(Br)Br</smiles>

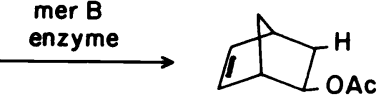

$\stackrel{4}{\sim}$

Whitesides and Sanfilippo (1970) used a nortricyclic mercurial (exo-3acetoxynortricyclyl-5-mercuric bromide), $\underline{3}$, and the bicyclic mercurial (cis-exobicyclo[2.2.1] hept-5-ene-2-acetoxy-3-mercuric bromide), 4 , to show that borohydride reduction yielded a constant mixture of nortricyclene and norbornene isomers, interpreted in favor of rapidly equilibrating radical intermediates. In contrast the organomercury lyase processes $\underline{3}$ and $\underline{4}$ only to the unrearranged products from $\mathrm{Hg}$ replacement by a proton (Scheme V). These results, coupled with no isomerization of cis-butenyl-mercurial 1 to trans butene and no isomerization of 2 to the exo-2-D $D_{1}$-norbornane ( $9 / 1$ exo/endo ratio seen from radical intermediates nonenzymically) all argue strongly against radical $\mathrm{S}_{\mathrm{H}}{ }^{2}$ type $\mathrm{C}$ Hg cleavage by the enzyme in substrates $\underline{1}-\underline{4}$.

\section{MECHANISTIC PROPOSAL}

We suggest the organomercuy lyase catalyzes organomercury $\mathrm{C}-\mathrm{Hg}$ bond cleavage by general acid catalysis and by participation of one or preferably two basic/nucleophilic groups (e.g. cysteine-SH groups) to activate the $\mathrm{C}-\mathrm{Hg}$ bond for protonolysis (Scheme VI). $\mathrm{X}$-ray structure of organomercurial complexes with amino acids suggests such secondary 
coordination (Wong et al, 1973, 1974; Furmanova et al, 1980) and nuceleophilic acceleration of electrophilic reactions of the carbon-mercury bond (for example, with $I_{2}$ ) are well-known (Beletskaya et al, 1965; Charman et a1, 1961; Kreevoy et al, 1966; Sayre and Jensen, 1979). Cleavage via $\mathrm{S}_{\mathrm{E}}{ }^{2}$ transition state would yield product hydrocarbon and bis enzyme-coordinated $\mathrm{Hg}$, to exchange with buffer thiol to yield free enzyme ready for another catalytic cycle. The rate acceleration seen with cis-butenyl mercury substrate suggests partial protonation to stabilize a carbenium ion contributor. The stabilization by metals in carbenium ion intermediates has been explained to propose the ready acid protonolyses of alkenyl metal species (Kreevoy and Kretchmer, 1964; Negishi, 1980). In accord with a rate-1imiting $S_{E^{2}}$ transition state is the solvent $D_{2} O$ Vmax isotope effect $\mathrm{VH}_{2} \mathrm{O} / \mathrm{VD}_{2} \mathrm{O}$ of 2.1 for cis-butenyl-Hg 1 seen with the enzyme (Begley, Walts, Walsh, 1986B).

The turnover numbers (1-240 $\left.\mathrm{min}^{-1}\right)$ for organomercurial protonolyses by this bacterial detoxification enzyme are relatively modest in the context of absolute rates of enzymic catalysts but are still $10^{6}-10^{7}$-fold faster than the equivalent chemical protonolysis rates (Begley, Walts, Walsh, 1986b). There is no obvious correlation of rates of chemical protonolysis or of carbon-mercury bond strengths with Vmax values of organomercury lyase. This is the first enzyme catalyzing organometallic cleavage to be isolated and characterized and may be a paradigm for such catalyst design. For example organotin compounds are widely dispersed in the environment from use as biocides in agriculture and in antifouling paints. Resistant organisms are known and may well protonolyze the tetravalent organostannanes. In this regard we have detected weak activity of organomercury lyase in converting tetravinyl tin to ethylene (Walts \& Walsh, 1986).

\section{REFERENCES}

Begley, T.P., Walts, A.E. and Walsh, C. T. (1986a) Biochemistry, in press.

Begley, T.P., Walts, A. E. and Walsh, C. T. (1986b) Blochemistry, in press.

Beletskaya, I.P., Myshkin, A.E. and Reutov, O.A. (1965) Bull. Acad. Sci. USSR, Div. Chem. Sci. 226.

Charman, H.B., Hughes, E.D., Ingold, C. and Volger, H.C. (1961) J. Chem. Soc. 1142.

Coad, J.R. and Johnson, M.D. (1967) J. Chem. Soc. (B), 633 .

Dodd, D. and Johnson, M.D. (1969) J. Chem. Soc. (B), 1071.

Furmanova, N.G., Kuz'mina, L.G., Struchkov, Y.T. (1980) in Organomet. Chem. Rev.

(Seyferth, D., ed) Elsevier, Amsterdam, 9, 153.

Halpern, J. (1985) Science 227, 869-875.

Hughes, E.D., Ingold, C.K., Roberts, R.M.G. (1964) J. Chem. Soc., 3900.

Ingold, K. U. and Roberts, B.P. (1971) in Free-Radical Substitution Reactions, Wiley, New York, p. 34 .

Jensen, F. R. and Rickborn, B. In Electrophilic Substitution of Organomercurials, McGrawHill, New York, 1968.

Kreevoy, M.M. (1957) J. Am. Chem. Soc. 79, 5927.

Kreevoy, M.M. and Hansen, R.I. (1961) J,Am. Chem. Soc. $83,626$.

Kreevoy, M.M. and Kretchmer, R.A. (1964) J. Am. Chem. Soc. 86, 2435.

Kreevoy, M.M., Steinwand, P.J. and Kayser, W.V. (1966) J. Am. Chem. Soc. $88,124$.

Negishi, E.-I. (1980) Organometallics in Organic Synthesis, Wiley, New York, Vo1. 1, pp. $422-430,475$.

Ragsdale, S.W. and Wood, H.G. (1985) J. Biol. Chem. 260, 3970-3977.

Sayre, L.M. and Jensen, F.R. (1979) J. Am. Chem. Soc. 101, 6001.

Walts, A. and Walsh, C (1986) Science, submitted.

Whitesides, G.M. and SanFilippo. Jr., J. (1970) J. Am. Chem. Soc. 92,6611 .

Williams, J.W. and Silver, S. (1984) Enz. Microb. Tech. 6, 530.

Wong, Y.S., Chieh, P.C. and Carty, A.J. (1973) Gan. J. Chem. 51, 2597.

Wong, Y. S., Taylor, N.J., Chieh, P. C. and Carty, A.J. (1974) J. Chem. Soc., Chem.

Commun., 625 . 